\title{
Aspartate and Glutamate Mediate Excitatory Synaptic Transmission in Area CA1 of the Hippocampus
}

\author{
Mark W. Fleck, ${ }^{1,2}$ Darrell A. Henze, ${ }^{1,2}$ German Barrionuevo,, ${ }^{1,2}$ and Alan M. Palmer ${ }^{2,3}$ \\ Departments of 'Behavioral Neuroscience, ${ }^{2}$ Psychiatry, and ${ }^{3}$ Pharmacology, University of Pittsburgh, Pittsburgh, \\ Pennsylvania 15260
}

\begin{abstract}
We examined whether L-aspartate (ASP) and L-glutamate (GLU) both function as endogenous neurotransmitters in area CA1 of the rat hippocampus. Radioligand displacement experiments using ${ }^{3} \mathrm{H}-\mathrm{DL}-\alpha$-amino-3-hydroxy-5-methylisoxazole-4-propionic acid ( ${ }^{3} \mathrm{H}-\mathrm{AMPA}$ ) to label AMPA/kainate receptors and ${ }^{3} \mathrm{H}$-cis-4-phosphonomethyl-2-piperidine carboxylic acid ( $3 \mathrm{H}-\mathrm{CGS}-19755)$ to label NMDA receptors confirmed that GLU $\left(K_{i} \sim 500 \mathrm{~nm}\right)$ but not ASP $\left(K_{i}>1 \mathrm{~mm}\right)$ has high affinity for AMPA/kainate receptors whereas GLU $\left(K_{i} \sim 250 \mathrm{nM}\right)$ and ASP $\left(K_{i} \sim 1.3 \mu \mathrm{M}\right)$ both have high affinity for NMDA receptors. Elevating extracellular potassium concentration (50 $\mathrm{mm}, 1 \mathrm{~min}$ ) evoked the calcium-dependent release of both ASP ( $\sim 50 \%$ increase) and GLU $(\sim 200 \%$ increase) from hippocampal slices and from minislices of area CA1. Reducing extracellular glucose concentration $\mathbf{0 . 2}$ $\mathrm{mM}$ ) reduced GLU release, enhanced ASP release, and reduced AMPA/kainate receptor-mediated responses more than NMDA receptor-mediated responses (to $7 \%$ and $34 \%$ of control, respectively). Fiber volleys, antidromic population spikes, membrane potential, input resistance, and ATP content all were not affected by glucose reduction. Unlike low glucose, the inhibitory neuromodulator adenosine (5 $\mu \mathrm{M})$, which reduces $A S P$ and GLU release to a similar extent, reduced AMPA/kainate and NMDA receptor-mediated population EPSPs similarly (to $11 \%$ and $12 \%$ of control, respectively). AMPA/kainate and NMDA receptor-mediated population EPSPs were also similarly reduced by $0.4 \mu \mathrm{M}$ TTX (to $32 \%$ and $22 \%$ of control, respectively) and similarly enhanced by $10 \mu \mathrm{M}$ 4-aminopyridine (to $206 \%$ and $248 \%$ of control, respectively). Finally, NMDA receptor-mediated EPSCs measured by whole-cell recording decayed faster in low glucose (73 msec vs 54 msec) but not in adenosine (73 msec vs $78 \mathrm{msec}$ ). Together, these results confirm that ASP and GLU are both involved in excitatory synaptic transmission at the Schaffer collateral-commissural terminals in area CA1 of the rat hippocampus.
\end{abstract}

[Key words: Schaffer collateral-commissurals, excitatory amino acids, transmitter release, receptor binding, electrophysiology, hypoglycemia, adenosine, ATP, brain slice]

\footnotetext{
Received Dec. 10, 1992; revised Mar. 4, 1993; accepted Mar. 23, 1993.

We are grateful to Mark Burns and Clara Reiter for their technical assistance and to Jon Johnson for his advice and comments. This work was supported by grants from NIA (AG08974-01), NINDS (RCDA NS01 196 and NS24288), AFOSR (91-0441), and NIMH (MH45156), and by predoctoral fellowships from NIMH and The Andrew Mellon Trust.

Correspondence should be addressed to German Barrionuevo, 446 Crawford Hall, University of Pittsburgh, Pittsburgh, PA 15260.
}

Copyright (C) 1993 Society for Neuroscience $0270-6474 / 93 / 133944-12 \$ 05.00 / 0$
Excitatory amino acid (EAA)-mediated neurotransmission is widespread throughout the mammalian CNS (Fagg and Foster, 1983; Cotman et al., 1987). Two EAAs, L-aspartate (ASP) and L-glutamate (GLU), satisfy most of the criteria for neurotransmitter status (Orrego, 1979) in various regions of the CNS (Fonnum, 1984; Mayer and Westbrook, 1987), including the hippocampus (Cotman and Nadler, 1981). Specifically, ASP and GLU are released in a calcium-dependent manner by electrical or chemical depolarization of neurons in various brain regions (Fonnum, 1984; Benveniste, 1989; Nicholls, 1989). They are effective at low concentrations (Surtees and Collins, 1985) and act at specific high-affinity receptors. Their exogenous action can be pharmacologically antagonized by many of the same compounds that block transmission at putative EAAergic synapses (Mayer and Westbrook, 1987; Monaghan et al., 1987). In addition, ASP and GLU appear to be concentrated in synaptic vesicles (Villanueva and Orrego, 1988; Villanueva et al., 1990; Van den Pol, 1991; but see Nicholls, 1989), although the only uptake carrier identified to date appears to be specific for GLU (Naito and Ueda, 1985; Fonnum, 1988; but see Dunlop et al., 1991). Finally, high-affinity uptake systems efficiently remove both ASP and GLU from extracellular space (Baclar and Johnson, 1972; Fonnum, 1984; Flott and Seifert, 1991).

The excitatory actions of EAAs are transduced by both ionotropic and metabotropic receptors (Mayer and Westbrook, 1987). Two general subtypes of ionotropic EAA receptors, AMPA/kainate receptors and NMDA receptors, are largely colocalized at EAAergic synapses (Bekkers and Stevens, 1989; Jones and Baughman, 1991). In contrast to AMPA/kainate receptors, NMDA receptors have relatively slow kinetics (Hestrin et al., 1990; Lester et al., 1990). In addition, NMDA receptors are regulated by numerous modulatory sites (Reynolds, 1990), including a binding site for magnesium ions (Mayer and Westbrook, 1984; Nowak et al., 1984) that regulates current flow through NMDA receptors in a voltage-dependent manner and greatly reduces NMDA receptor involvement in fast synaptic transmission. GLU is a potent agonist at all EAA receptors yet characterized whereas ASP appears to be a selective NMDA receptor agonist (Olverman et al., 1988; Verdoorn and Dingledine, 1988; Patneau and Mayer, 1990).

Brain GLU appears to be derived primarily from two sources (Hamberger et al., 1979a,b; Fonnum, 1988; Hertz and Schousboe, 1988; Shank and Aprison, 1988; Tildon and Zielke, 1988): (1) by conversion of $\alpha$-ketoglutarate, which is derived from glucose via the tricarboxylic acid (TCA) energy metabolic cycle, and (2) by conversion of glutamine, an intermediary in nitrogen metabolism. The law of mass action determines the net direction of GLU flow into or out of the TCA cycle; when glucose con- 
centration and glycolysis are reduced, acetyl-CoA formation is limited, less $\alpha$-ketoglutarate is derived, and so the equilibrium changes to favor GLU catabolism via the TCA cycle over GLU synthesis. GLU is reversibly converted to $\alpha$-ketoglutarate by the cytosolic enzyme ASP transaminase (Asp-T; also known as ASP aminotransferase), by which ASP is also produced (Cooper, 1988). Glutamine is derived mainly from astrocytes and can serve as a precursor to GLU formation by the enzyme glutaminase. Thus, the concentrations of ASP and GLU are determined by the relative concentrations of glucose and glutamine (Fig. 1). This scheme is consistent with observations that the ratio of released ASP:GLU is sensitive to hypoglycemia both in vivo (Sandberg et al., 1986) and in vitro (Szerb and O'Regan, 1987; Szerb, 1988; Nadler et al., 1990).

Recent immunocytochemical studies in hippocampus, where concomitantly evoked release of ASP and GLU is often reported (Nadler et al., 1976; Spencer et al., 1981; Ferkany and Coyle, 1983; Wierasko, 1983; Szerb and O'Regan, 1985, 1987; Burke and Nadler, 1988; Szerb, 1988; Nadler et al., 1990; Martin et al., 1991; Palmer et al., 1992), have revealed a substantial overlap between ASP- and GLU-like immunoreactivities in the terminal fields of excitatory afferents to area CAl (Gundersen et al., 1991). These observations suggest that ASP and GLU can act as cotransmitters at these hippocampal synapses. Still, because ASP is a less potent agonist than GLU and because no uptake carrier has yet been demonstrated to concentrate ASP in synaptic vesicles, it has been proposed that ASP may not act as a neurotransmitter at all (Nicholls, 1989). By this argument, ASP release, although calcium dependent, is an artifact of GLU release and is observed only because of a nonphysiological reversal of high-affinity uptake.

Here, we tested whether endogenous ASP acts as a neurotransmitter at the Schaffer collateral-commissural synapses of the hippocampus by manipulating releasable ASP and GLU and measuring the resulting changes in pharmacologically isolated AMPA/kainate and NMDA receptor-mediated responses recorded in area CA1. Results confirm that excitatory transmission at these synapses involves both ASP and GLU. However, the actions of these transmitters are not identical; ASP activates only NMDA receptors whereas GLU activates both NMDA and AMPA/kainate receptors.

A preliminary account of portions of this work has been reported previously (Fleck et al., 1991).

\section{Materials and Methods}

Radioligand binding. The interactions of ASP and GLU with both AMPA/kainate and NMDA receptors was assessed using displacement of bound ${ }^{3} \mathrm{H}$-DL- $\alpha$-amino-3-hydroxy-5-methylisoxazole-4-propionic acid ( ${ }^{3} \mathrm{H}$-AMPA; New England Nuclear, Boston, MA) and $\left({ }^{3} \mathrm{H}-c i s-4-p h o s-\right.$ phonomethyl-2-piperidine carboxylic acid ( ${ }^{3} \mathrm{H}-\mathrm{CGS}-19755$; New England Nuclear), respectively. Rats were decapitated and hippocampi were removed, weighed, and frozen. Later, the hippocampi were thawed $\left(37^{\circ} \mathrm{C}, 20 \mathrm{~min}\right)$ in $15 \mathrm{ml}$ of Tris-acetate buffer $(50 \mathrm{~mm}, \mathrm{pH} 7.4)$ containing $140 \mathrm{~mm} \mathrm{KCl}$ (to deplete neurotransmitter stores by depolarizing membranes and reversing high-affinity uptake). Then, hippocampi were removed into 9 vol of ice-cold $50 \mathrm{~mm}$ Tris-acetate buffer, homogenized using a Polytron homogenizer, and centrifuged $(42,000 \times \mathrm{g}, 25 \mathrm{~min}$, $4^{\circ} \mathrm{C}$ ). Then, the lissue was washed four times by removing the supernatant, resuspending the pellet in $50 \mathrm{vol}$ of $5 \mathrm{~mm}$ Tris-acetate buffer, and centrifuging $\left(42,000 \times \mathrm{g}, 25 \mathrm{~min}, 4^{\circ} \mathrm{C}\right)$. The resultant pellet was stored overnight at $-70^{\circ} \mathrm{C}$. On the day of the experiment, the pellets were thawed $\left(30^{\circ} \mathrm{C}, 15 \mathrm{~min}\right)$ in $5 \mathrm{~mm}$ Tris-acetate buffer and incubated for an additional 15 min with $0.05 \%$ Triton X-100 added. Then, pellets were resuspended in $50 \mathrm{vol}$ of $5 \mathrm{~mm}$ Tris-acetate buffer and centrifuged $\left(42,000 \times g, 25 \mathrm{~min}, 4^{\circ} \mathrm{C}\right)$. This washing was repeated two more times

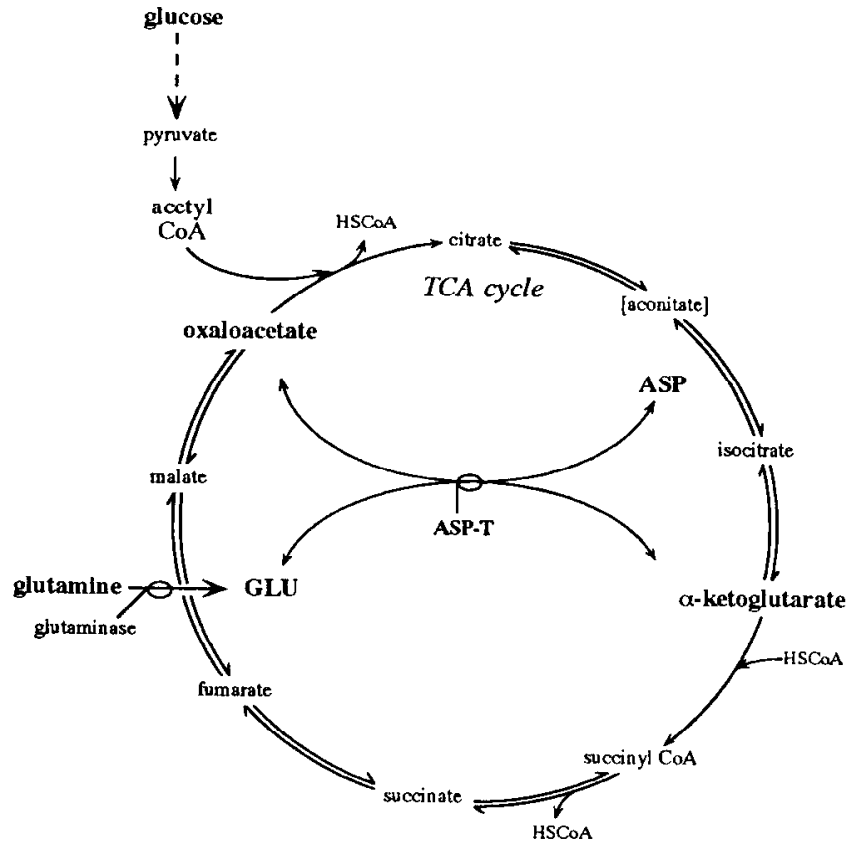

Figure 1. Alternate pathways for glutamate $(G L U)$ and aspartate $(A S P)$ synthesis. GLU can be produced from glutamine, which is normally abundant in extracellular space (approximately $0.5 \mathrm{~mm}$ ) and is deaminated in neurons by the enzyme glutaminase to form GLU. GLU is also produced from $\alpha$-ketoglutarate, an intermediate in the tricarboxylic acid (TCA) energy metabolic cycle. The cytosolic enzyme ASP transaminase (Asp-T; also called ASP aminotransferase) catalyzes the reversible reaction: $\mathrm{GLU}+$ oxaloacetate $\Rightarrow \mathrm{ASP}+\alpha$-ketoglutarate. Asp-T is critically involved in regulating the entry and exit of carbon from the TCA cycle as dictated by the equilibrium of the substrates of the reaction. Thus, the equilibrium concentrations of ASP and GLU depends on the relative concentrations of glutamine and glucose. Reducing glucose availability should reverse GLU synthesis from $\alpha$-ketoglutarate, causing instead GLU metabolism in the TCA cycle and increased production of ASP.

using $5 \mathrm{~mm}$ Tris-acetate buffer. Binding assays were performed with approximately $0.5 \mathrm{mg}$ of protein in a final volume of $0.5 \mathrm{ml}$ of Trisacetate buffer ( $5 \mathrm{mM}$ ), various concentrations of ASP or GLU, and either $10 \mathrm{nM}{ }^{3} \mathrm{H}$-AMPA with $100 \mathrm{~mm}$ potassium thiocyanate or $10 \mathrm{nM}{ }^{3} \mathrm{H}$ CGS-19755. Incubations were performed on ice in triplicate for either $1 \mathrm{hr}\left({ }^{3} \mathrm{H}\right.$-AMPA) or $15 \mathrm{~min}\left({ }^{3} \mathrm{H}\right.$-CGS-19755). Incubations were terminated by rapid filtration over glass fiber filters (Whatman $G F / B$ ), and following rapid washing and immersion in biodegradable scintillation fluid, the radioactivity was determined by liquid scintillation spectrometry. Residual binding in $1 \mathrm{~mm}$ L-glutamate was considered to be nonspecific and was typically $15 \%$ of total binding for both ${ }^{3} \mathrm{H}-\mathrm{AMPA}$ and ${ }^{3} \mathrm{H}$-CGS-19755. Displacement constants were determined separately for each experiment using ACCUFIT SATURATION TWO-SITES software for IBM PC (Lundon Software, Chagrin Falls, OH).

Preparation and maintenance of hippocampal slices. Hippocampal slices were prepared in a conventional manner from male SpragueDawley rats (125-250 gm; from Zivic-Miller, Zelienople, PA). Briefly, animals were decapitated and both hippocampi were removed and cut using a vibratome to obtain $500-\mu$ m-thick transverse slices. For most experiments, minislices of area CAl were prepared by removing most of the CA3 and dentate regions. Sliccs were incubated in oxygenated artificial cerebrospinal fluid (ACSF) before use. Standard ACSF consisted of the following (in $\mathrm{mM}$ ): $\mathrm{NaCl}, 125 ; \mathrm{KCl}, 3 ; \mathrm{NaH}_{2} \mathrm{PO}_{4}, 1.25$ $\mathrm{MgCl}_{2}, 2.1 ; \mathrm{CaCl}_{2}, 2.3 ; \mathrm{NaHCO}_{3}, 26$; saturated with $95 \% \mathrm{O}_{2}, 5 \% \mathrm{CO}_{2}$

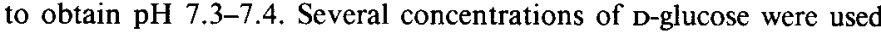
ranging from 0 to $10 \mathrm{~mm}$. In some experiments, $0.5 \mathrm{~mm}$ L-glutamine was also included in the ACSF.

Release of excitatory amino acids. Amino acid release was measured from individual hippocampal slices perfused at a rate of $800 \mu \mathrm{l} / \mathrm{min}$. Samples of efflux were collected in $1 \mathrm{~min}$ fractions and immediately frozen for subsequent analysis. Frozen perfusate samples were thawed 

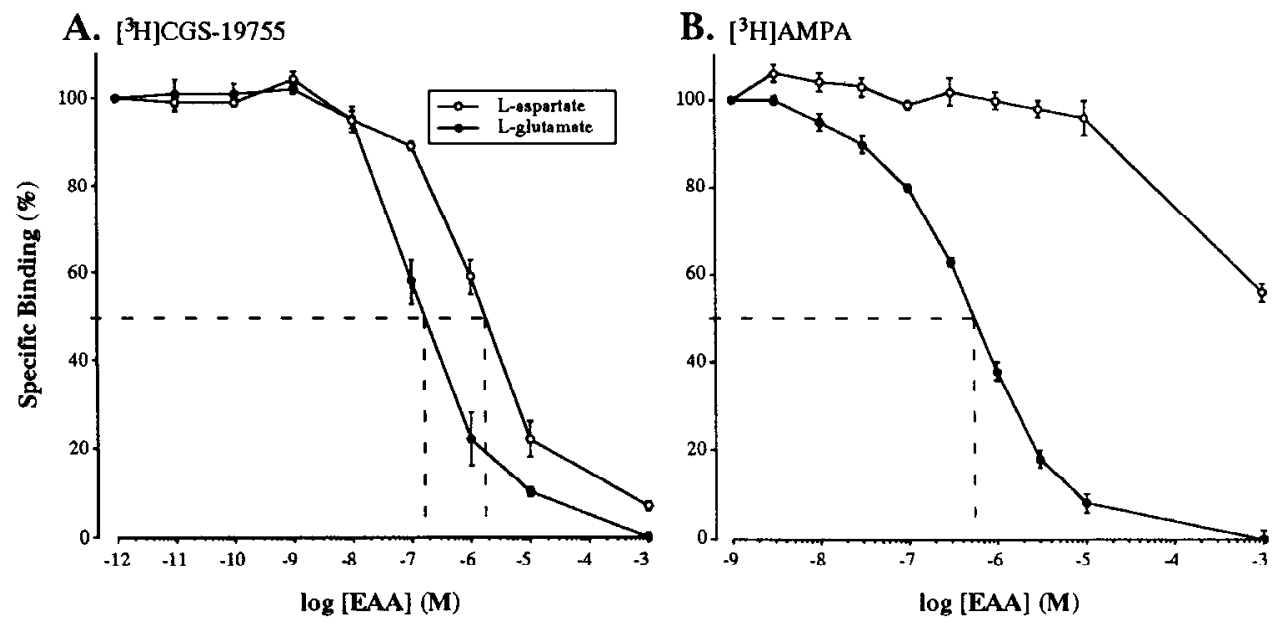

Figure 2. ASP and GLU displacement of NMDA and AMPA/kainate receptor radioligand binding to hippocampal membranes. Hippocampal membranes were incubated in either $10 \mathrm{nM}{ }^{3} \mathrm{H}$-CGS-19755 $(A)$ or $10 \mathrm{nM}{ }^{3} \mathrm{H}$-AMPA $(B)$ with various concentrations of ASP or GLU included and the reaction terminated by rapid filtration. $A$, GLU (solid circles) and ASP (open circles) displacement of ${ }^{3} \mathrm{H}-\mathrm{CGS}-19755$ was used to assess relative binding affinities at NMDA receptors. $B$, GLU (solid circles) and ASP (open circles) displacement of ${ }^{3} \mathrm{H}$-AMPA was used to assess relative binding affinities at AMPA/kainate receptors. Membrane preparations were incubated with various ligand concentrations on ice for 15 min $\left({ }^{3} \mathrm{H}\right.$-CGS19755 ) or for $1 \mathrm{hr}\left({ }^{3} \mathrm{H}\right.$-AMPA). Experiments were performed in triplicate, using three independent membrane preparations for ${ }^{3} \mathrm{H}-\mathrm{CGS}-19755$ displacement and two independent membrane preparations for ${ }^{3} \mathrm{H}$-AMPA displacement. Displacement constants were determined using ACcuFIT SATURATION TWO-SITES software. Results are expressed as mean \pm SEM.

at room temperature and centrifuged (Sigma 3 K20, B. Braun Biotech, Osterode, Germany) for $5 \mathrm{~min}$ to precipitate any cellular debris. After pre-column derivitization with $o$-phthaldialdehyde (OPA), amino acids were separated by high-pressure liquid chromatography (HPLC) and quantified relative to known standards by fluorescence detection. The apparatus (Waters Chromatography, Milford, MA) consisted of two pumps (model 501), an automatic sample injector (WISP model 715), a fluorescence detector (model 470 , excitation $334 \mathrm{~nm}$ and emission $424 \mathrm{~nm}$ ), a temperature control module, a column heater module, and a microcomputer-based control system (model M820). Samples containing amino acids $(40 \mu \mathrm{l})$ were mixed with OPA-mercaptoethanol reagent (Pierce Chemical Co., Rockford, IL) and injected onto the column after a 1 min mixing step. A reverse-phase column $(50 \times 4.6 \mathrm{~mm}$ i.d.) was employed with a guard column $(15 \times 4.6 \mathrm{~mm}$ i.d.), both packed with octadecylsilane particles $3 \mu \mathrm{m}$ in diameter (Microsorb, Rainin Instrument (o., Woburn, MA) and contained in an axial compression unit (Dynamax, Rainin Instrument Co.) at a temperature of $30^{\circ} \mathrm{C}$. The mobile phase was a mixture of $50 \mathrm{~mm}$ HPLC-grade orthophosphoric acid (adjusted to $\mathrm{pH} 5.7$ with $\mathrm{NaOH}$ and containing $50 \mu \mathrm{M}$ ethylenediaminetetra-acetic acid) and HPLC-grade methanol (Baxter Scientific Products, McGaw Park, II ). These two solutions were mixed in the vol: vol ratio of 90:10 for solvent A and 10:90 for solvent B. A curvilinear gradient was used to change the proportion of solvent A from $90 \%$ to $10 \%$ over $7.5 \mathrm{~min}$ and return to $90 \%$ over $5 \mathrm{~min}$. Peaks were identified by comparing retention times with those of authentic standards under a number of chromatographic conditions. Peak areas were quantified using MAXIMA 820 software (Dynamic Solutions Inc., Ventura, CA). This procedure provided consistent and adequate separation to quantify the amino acids aspartate, glutamate, serine, glutamine, and glycine. Amino acid concentrations as low as $0.2 \mathrm{pmol} / 40 \mu \mathrm{l}(5 \mathrm{nM})$ could be quantified reliably. Low-level background contamination in the HPLC buffers prevented any improved sensitivity.

Minislices were used in addition to whole slices to verify that the amino acid release we measured was derived from area CA1. Standard ACSF was prepared as described above. Constant flow through a 250$\mu \mathrm{l}$-volume submerged perfusion chamber was maintained using a peristaltic pump (model 202U1, Watson-Marlow, Falmouth, England). Perfusate samples were collected in 1 min fractions $(800 \mu \mathrm{l})$, and IIPLC was used to determine the amino acid content of four effluent samples taken before, and four effluent samples taken during and immediately following, high-potassium stimulation. High-potassium stimulation $(50$ $\mathrm{mM}$ for $1 \mathrm{~min}$ ) was presented after slices had been allowed to equilibrate in the perfusion chamber for at least $15 \mathrm{~min}$. Similar experiments were performed in low-calcium ACSF containing $0.5 \mathrm{mM} \mathrm{CaCl}, 3 \mathrm{~mm} \mathrm{MgCl}$, and $0.5 \mathrm{~mm}$ EGTA. Basal release was calculated as the average amino acid content of the four effluent samples taken immediately before highpotassium stimulation. Evoked release was calculated from the peak increase above basal levels (percentage of control) measured in the following four samples.

ATP measurements. Tissue content of adenosine triphosphate (ATP) was calculated from a firefly luciferase assay (Sigma, FL-AAM). CA1 minislices were preincubated for $1 \mathrm{hr}$ in standard ACSF, after which they were separated into three groups and incubated at room temperature for $1 \mathrm{hr}$ longer in ACSF containing either $10 \mathrm{~mm}, 1.0 \mathrm{~mm}$, or 0.2 $\mathrm{mM}$ glucose. Slices were then collected in reagent containing an $\Lambda \mathrm{TP}$ releasing ionophore (Sigma, FL-SAR), vortexed, and rapidly frozen in a dry-ice/ethanol bath. On the following day, tissue preparations were rapidly thawed and centrifuged $\left(42,000 \times \mathrm{g}, 5 \mathrm{~min}, 4^{\circ} \mathrm{C}\right)$. Triplicate samples of $100 \mu \mathrm{l}$ were added with $100 \mu \mathrm{l}$ luciferin/luciferase assay buffer to $10 \mathrm{ml}$ of phosphate buffer $(0.01 \mathrm{M}, \mathrm{pH} 7.8)$. Bioluminescence was determined by liquid scintillation spectrometry. ATP content was quantified relative to known standards and corrected for protein content of the tissue preparations as determined by the method of Smith et al. (1985) using bovine serum albumin as the standard.

Extracellular recordings. CA I minislices were individually transferred to the submerged recording chamber wherein they were continuously perfused $(800 \mu \mathrm{l} / \mathrm{min})$ with fresh, oxygenated ACSF at room temperature $\left(20 \pm 2^{\circ} \mathrm{C}\right)$. Extracellular recording micropipettes were pulled from 1.5mm-o.d. borosilicate glass tubing, filled with $0.5 \mathrm{M} \mathrm{NaCl}$, and selected for tip resistances of $1-3 \mathrm{M} \Omega$ measured in $0.9 \%$ saline. Bipolar stimulating electrodes were made with $62 \mu \mathrm{m}$ diameter insulated nichrome wire. Extracellular field recordings of population excitatory postsynaptic potentials (pEPSPs) were obtained from stratum radiatum of the CAl subregion. A bipolar stimulating electrode was placed in stratum radiatum of CA1 for orthodromic stimulation of the Schaffer collateralcommissural afferents at $0.2 \mathrm{~Hz}$. Pulse duration was fixed at $100 \mu \mathrm{sec}$. Stimulus intensity was set to elicit pEPSPs that were just subthreshold for the elicitation of a population spike, except in experiments using 4-aminopyridine (4-AP), when stimulus intensity was set to elicit pEPSPs of approximately half-threshold for population spiking. Sampled field potentials were displayed on a Nicolet oscilloscope, digitized, and stored on an IBM-386 system hard drive for subsequent off-line analysis. When used, the following drug concentrations were added to perfusion medium: $10 \mu \mathrm{M}$ 6-cyano-7-nitroquinoxaline-2,3-dione (CNQX; Tocris Neuramin, Essex, England), $20 \mu \mathrm{M}$ D-2-amino-5-phosphonovaleric acid (D-APV; Research Biochemicals Inc., Natick, MA), $10 \mu \mathrm{M}$ 4-AP (Sigma, St. Louis, MO), $0.4 \mu \mathrm{M}$ tetrodotoxin (TTX; Sigma), $5 \mu \mathrm{M}$ adenosine (Sigma). CNQX solutions also included $0.05 \%$ final concentration dimethyl sulfoxide to aid solubility.

Intracellular and whole-cell recordings. CA1 minislices were prepared 
A. WHOLE SLICES

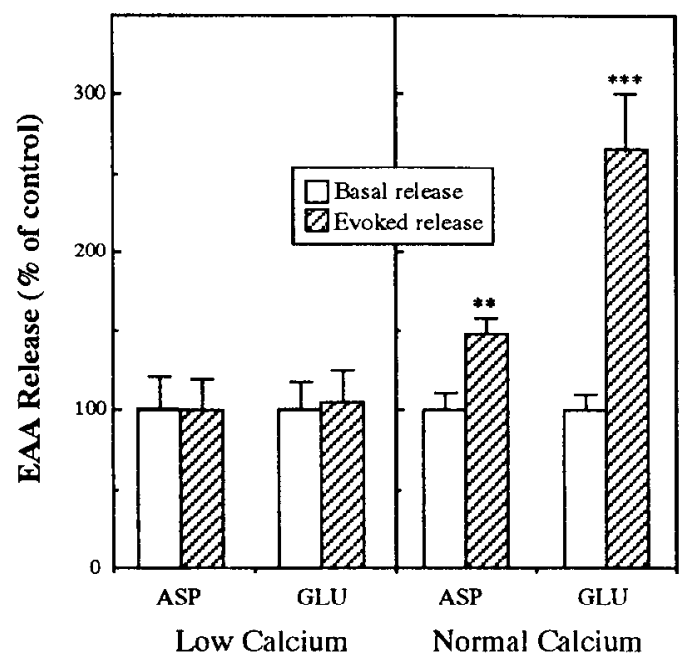

B. CA1 MINISI.ICES

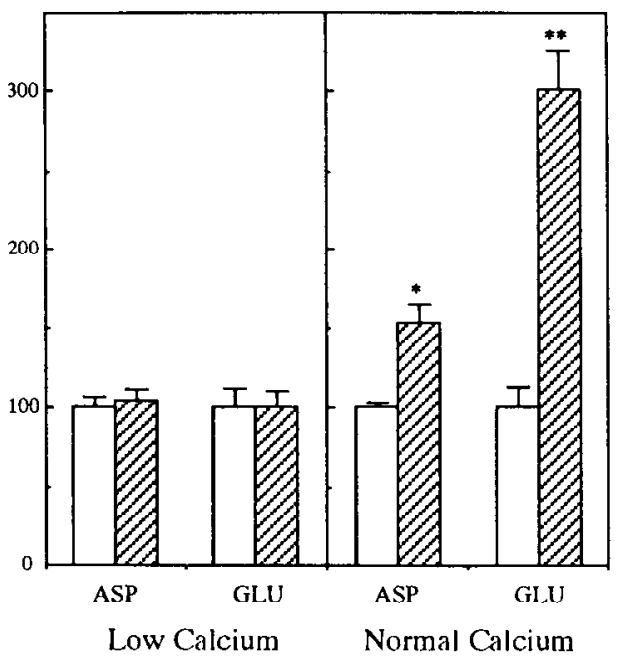

Figure 3. Calcium-dependent potassium-evoked release of endogenous ASP and GLU from whole slices and from minislices of area CA1. Slices were incubated in normal- or low-calcium medium for $15 \mathrm{~min}$ (Basal release) prior to 1 min stimulation with $50 \mathrm{mM} \mathrm{KCl} \mathrm{(Evoked} \mathrm{release).} \mathrm{Perfusate}$ samples were collected in $1 \mathrm{~min}$ fractions and endogenous EAAs were measured by HPLC with fluorometric detection. Peak increases were normalized to basal values and averaged. High potassium failed to evoke increases from basal EAA release in low-calcium ACSF from either whole slices $(n=6 ; A)$ or CA1 minislices $(n=3 ; B)$. Significant potassium-evoked EAA release was observed in normal-calcium ACSF from whole slices $(n=10)$ and CAl minislices $(n=3)$. Asterisks denote statistically significant increases from basal values $\left(^{*}, p<0.02 ;{ }^{* *}, p<0.01 ;{ }^{* * *}, p<0.001\right.$; one-tailed $t$ tests). Results are expressed as mean \pm SEM.

as in extracellular experiments, above. Intracellular current-clamp recordings were obtained from presumed pyramidal cells in minislices of area CAl. Intracellular recording micropipettes were pulled from 1.5$\mathrm{mm}-\mathrm{o} . \mathrm{d}$. borosilicate glass, filled with $1 \mathrm{M} \mathrm{KCl}$, and selected for tip resistances of 30-60 MR. Cells were impaled while CAl minislices were perfused with standard ACSF ( $10 \mathrm{~mm}$ glucose). Current-clamp recordings were obtained using an Axoclamp-2A (Axon Instruments). After a stable baseline was recorded, the glucose concentration in the perfusion medium was reduced to 1.0 or $0.2 \mathrm{~mm}$. EPSP amplitude, membrane potential, and input resistance were measured and compared in the two conditions. Whole-cell recordings were performed using the blind method (Blanton et al., 1989). Whole-cell recording micropipettes were pulled from 7052 glass (Garner Glass) and filled with a solution consisting of (in mM) $125 \mathrm{CsCH}_{4} \mathrm{OS}_{3}, 15 \mathrm{NaCl}, 10 \mathrm{HEPES}, 1$ BAPTA-K ${ }_{4}, 0.1 \mathrm{CaCl}_{2}$, $1 \mathrm{MgSO}_{4}, 2.0 \mathrm{Mg}$-ATP, and 1 picrotoxin. Final $\mathrm{pH}$ was adjusted to 6.7 , and osmolarity was $270 \mathrm{mOsm}$. Final tip resistances were 3-6 M $\Omega$. NMDA responses were isolated as described above, but with $10 \mu \mathrm{M}$ picrotoxin, and $10 \mu \mathrm{M}$ bicuculline also added to expose the decay currents of pure NMDA receptor-mediated synaptic responses. Voltageclamp recordings were obtained using an Axopatch-1D amplifier (Axon Instruments). Series resistance was monitored and data were discarded if large changes were observed during the course of data collection. Decay-time constants of averaged EPSCs were measured using AXOGRAPH software for Macintosh (Axon Instruments).

Data analyses and statistics. Data are presented as mean \pm SEM. Paired $t$ tests were used for planned comparisons of basal versus potassium-evoked EAA release in normal-calcium, low-calcium, and lowglucose ACSF. Paired $t$ tests were also used to compare baseline EPSPs with those observed in low glucose, adenosine, TTX, and 4-AP. Independent $t$ tests were used for all other comparisons. The level of statistical significance was set at $p<0.05$.

\section{Results}

\section{EAA receptor binding}

We first sought to determine the relative affinities of ASP and GLU at AMPA/kainate receptors and NMDA receptors. Hippocampal membranes were prepared as described in Materials and Methods and used to test for ASP and GLU displacement of bound ${ }^{3} \mathrm{H}$-AMPA, a high-affinity AMPA/kainate receptor agonist (Murphy et al., 1987), or bound ${ }^{3} \mathrm{H}-\mathrm{CGS}-19755$, a highaffinity NMDA receptor antagonist (Lehmann et al., 1988; Mur- phy et al., 1988) (Fig. 2). GLU effectively displaced ${ }^{3} \mathrm{H}$-AMPA binding with a $K$, of $\sim 250$ nM. ASP displaced less than $50 \%$ ${ }^{3} \mathrm{H}$-AMPA binding at the highest concentration tested $\left(K_{i}>1\right.$ mM). GLU effectively displaced ${ }^{3} \mathrm{H}-\mathrm{CGS}-19755$ binding with a $K_{i}$ of $\sim 500$ nM. ASP also effectively displaced ${ }^{3} \mathrm{H}-\mathrm{CGS}-19755$ binding with a $K_{i}$ of $\sim 1300$ nM. Thus, we observed a ratio of more than 2000:1 of GLU:ASP binding at AMPA/kainate receptors and an approximate 5:1 ratio of GLU:ASP binding at NMDA receptors under the present conditions. These results are consistent with previous reports for binding to cortical membranes (Olverman et al., 1988), where an approximate 11:1 ratio of GLU:ASP binding was measured by displacement of D-APV. Binding results also correlate well with physiological data from several groups who measured ASP- and GLU-evoked responses in hippocampal cells (Patneau and Mayer, 1990) and receptors in Xenopus oocyte expression systems (Verdoorn and Dingledine, 1988) and reported an approximate 6:1 ratio of GLU:ASP $\mathrm{EC}_{50}$ values at NMDA receptors.

\section{$E A A$ release}

Next, we examined endogenous ASP and GLU release evoked from hippocampal slices by potassium-induced depolarization. Sixteen whole hippocampal slices were individually perfused for $1 \mathrm{~min}$ with high-potassium $(50 \mathrm{~mm})$ medium to test for potassium-evoked release of EAAs. High-potassium medium evoked the release of both ASP ( $266 \pm 42 \%$ of basal) and GLU ( $389 \pm 54 \%$ of basal) but did not affect the concentrations of serine or glycine in the perfusate. Glutamine efflux was often decreased in high potassium. To determine whether potassiumevoked EAA release was calcium dependent, whole hippocampal slices were perfused with either normal-calcium $(n=10)$ or low-calcium $(n=6)$ ACSF (Fig. 3A). Data for ASP was discarded for one of the 10 slices tested in normal calcium because of inadequate HPLC separation of the ASP peak. High-potassium exposure in normal- but not in low-calcium ACSF caused a 


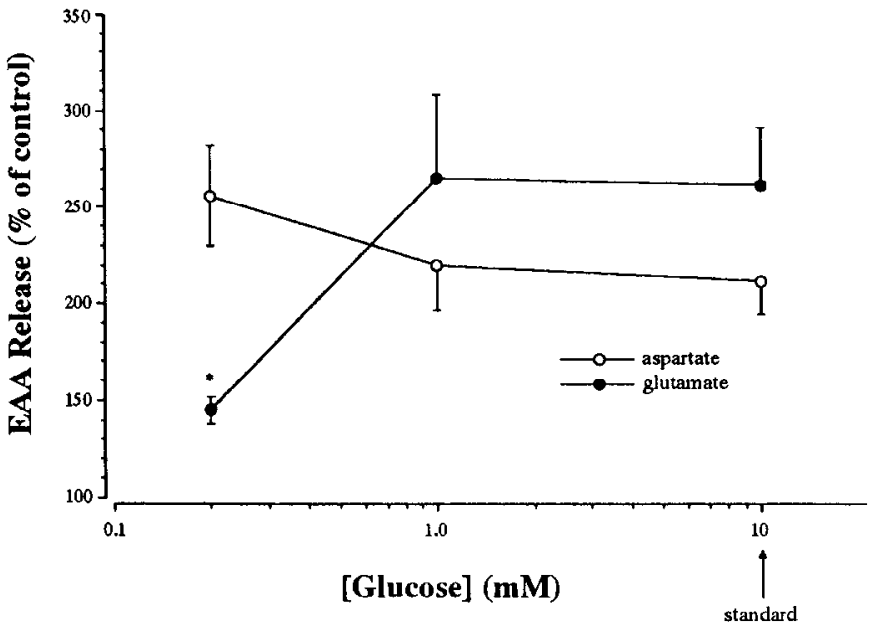

Figure 4. Effects of low glucose concentration on potassium-evoked EAA release. Hippocampal slices were incubated for more than $1 \mathrm{hr}$ in ACSF containing $10(n=5), 1.0(n=5)$, or $0.2(n=5) \mathrm{mm}$ glucose. Glutamine $(0.5 \mathrm{~mm})$ was supplemented in each condition. Perfusate samples were collected in $1 \mathrm{~min}$ fractions. Four basal release samples were collected, slices were stimulated for $1 \mathrm{~min}$ with $50 \mathrm{~mm} \mathrm{KCl}$, and four evoked release samples were collected. Endogenous GLU (solid circles) and ASP (open circles) in the perfusate samples were measured by HPLC with fluorometric detection. Peak increases were normalized to basal release values and averaged. Data are expressed as mean \pm SEM. Astcrisk indicates $p<0.05$, two-tailed $t$ test corrected for multiple comparisons.

significant increase in perfusate concentrations of ASP ( $p<$ 0.01 , one-tailed $t$ test) and GLU ( $p<0.001$, one-tailed $t$ test). Potassium-evoked EAA release was also measured from minislices of isolated area CA1 in normal-calcium $(n=5)$ and lowcalcium ( $n=3$ ) ACSF (Fig. $3 B$ ). As in whole slices, high-potassium exposure in normal- but not in low-calcium ACSF caused a significant increase in perfusate concentrations of both ASP ( $p<0.02$, one-tailed $t$ test) and GLU ( $p<0.01$, one-tailed $t$ test).

\section{ASP contribution to synaptic transmission}

We assessed the ASP contribution to hippocampal synaptic transmission by manipulating the releasable pools of ASP and GLU and measuring the resultant changes in evoked pEPSPs. To manipulate releasable ASP and GLU, slices were incubated in various concentrations of glucose prior to 1 min stimulation with $50 \mathrm{~mm} \mathrm{KCl}(n=15)$. Decreased glucose availability was expected to increase GLU catabolism in the TCA cycle (see Fig. 1), thus producing a net decrease in GLU release and a net increase in ASP release. Slices were preincubated for at least 1 hr in ACSF containing either 10, 1.0 , or $0.2 \mathrm{~mm}$ glucose. Glutamine $(0.5 \mathrm{~mm})$ was supplemented in each condition as an alternate metabolic source. In $10 \mathrm{~mm}$ glucose, high potassium evoked an increase in both GLU (261 $\pm 30 \%$ of basal) and ASP (210 $\perp 16 \%$ of basal) (Fig. 4). Reducing glucose concentration to $1.0 \mathrm{~mm}$ had no measurable effect on EAA release, although further reduction to $0.2 \mathrm{~mm}$ glucose was associated with a decrease in potassium-evoked GLU release ( $145 \pm 7 \%$ of basal) and an increase in potassium-evoked ASP release $(256 \pm 26 \%$ of basal). Basal release of ASP and GLU was not different in low glucose.

We then conducted a series of experiments examining the concentrations of glucose and duration of glucose deprivation

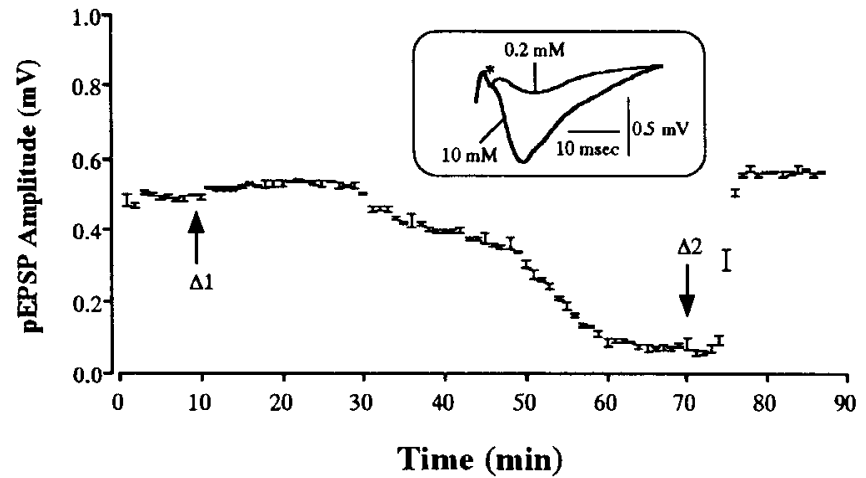

Figure 5. Effects of low glucose concentration on Schaffer collateralcommissural pEPSPs. Data are taken from a representative experiment in which pEPSPs were recorded in area CA1 of the hippocampal slice in response to Schaffer collateral-commissural stimulation. During baseline, the slice is superfused with standard ACSF containing $10 \mathrm{~mm}$ glucose. After a stable baseline response is recorded, the perfusion medium is changed to one containing low $(0.2 \mathrm{~mm}$ ) glucose (first arrow). Individual traces were pooled into bins of 12 responses each $(1 \mathrm{~min})$, and peak amplitudes of the pEPSPs are expressed as mean \pm SEM. At the end of the experiment, the perfusion glucose concentration was restored to $10 \mathrm{~mm}$ (second arrow) to assess the recovery of pEPSP amplitudes. Inset shows superimposed waveforms (averages of 15 consecutive traces) recorded in standard- and low-glucose ACSF. Asterisk indicates the presumed presynaptic fiber volley that was not reduced in low glucose.

necessary to reduce Schaffer collateral-commissural pEPSPs. pEPSPs from CA1 were recorded in $10 \mathrm{~mm}$ glucose ACSF. After a stable baseline response had been established, the perfusion medium was changed to low-glucose ACSF. We observed that pEPSPs were not affected by decreasing to $5.0,2.5$, or $1.0 \mathrm{~mm}$ glucose. However, at $0.2 \mathrm{~mm}$ glucose, the peak amplitude of pEPSPs declined slowly, reaching a stable plateau at $14 \pm 3 \%$ of baseline $(n=5)$ after approximately $1 \mathrm{hr}$ (Fig. 5). Similarly, the initial slopes of pEPSPs were not affected in $1.0 \mathrm{~mm}$ glucose but were reduced to $9 \pm 3 \%$ of baseline in $0.2 \mathrm{mM}$ glucose.

Because release of $\Lambda$ SP, a high-affinity NMDA but not AMPA kainate receptor agonist, persisted in $0.2 \mathrm{~mm}$ glucose, we hypothesized that the residual pEPSP observed in low glucose was mediated by ASP acting at NMDA receptors. We tested this hypothesis by measuring the reduction in isolated AMPA/kainate and NMDA receptor-mediated pEPSPs after changing from standard- to low-glucose ACSF. To isolate AMPA/kainate receptor-mediated pEPSPs, $20 \mu \mathrm{M}$ D-APV, an NMDA receptor antagonist, was included in the perfusion medium. To isolate NMDA receptor-mediated pEPSPs, $10 \mu \mathrm{M}$ CNQX, an AMPA/ kainate receptor antagonist, was included and magnesium concentration was reduced to $100 \mu \mathrm{M}$. Isolated AMPA/kainate receptor-mediated pEPSPs peaked approximately $5 \mathrm{msec}$ after the termination of the presynaptic fiber volley whereas the slower NMDA receptor-mediated pEPSPs peaked after approximately $20 \mathrm{msec}$ (Fig. 6A) and were evoked with greater stimulation intensity. Isolated AMPA/kainate or NMDA receptor-mediated pEPSPs were monitored continuously while glucose concentration in the perfusion medium was reduced from $10 \mathrm{~mm}$ to $1.0,0.5$, or $0.2 \mathrm{mM}$. Both AMPA/kainate (Fig. $6 B$ ) and NMDA (Fig. $6 C$ ) receptor-mediated pEPSPs were reduced at low glucose concentrations. At $1.0 \mathrm{~mm}$ glucose, both initial slopes and peak amplitudes of NMDA receptor-mediated responses were increased slightly (both $p<0.05$, two-tailed $t$ test). This increase was not expected from our release data but might be indicative 
A

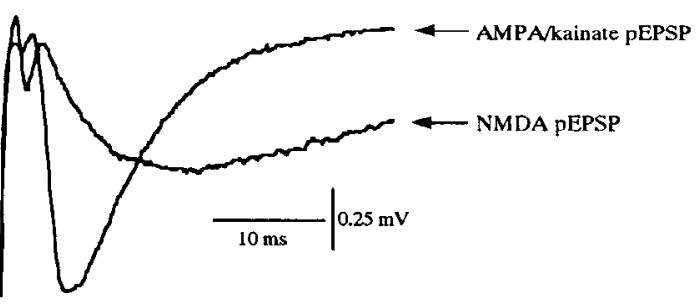

B
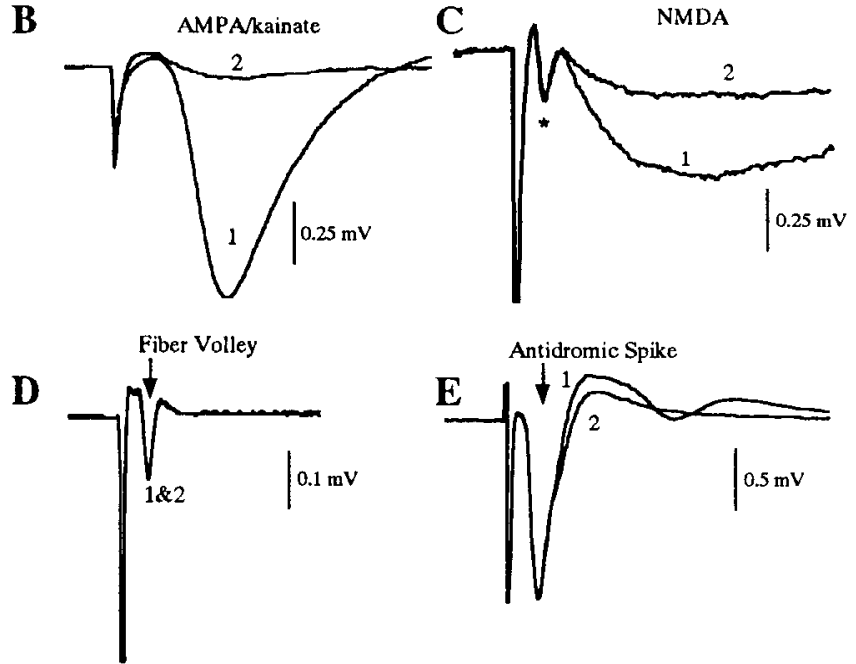

Figure 6. Effects of low glucose concentration on isolated AMPA kainate and NMDA receptor-mediated responses. pEPSPs were evoked by Schaffer collateral stimulation in minislices of area CA1. A, Superimposed AMPA/kainate and NMDA receptor-mediated components of pEPSPs are shown. Responses were evoked by stimulation of the Schaffer collateral-commissural afferents in minislices of area CA1 from independent experiments. To isolate AMPA/kainate receptor-mediated currents, $20 \mu \mathrm{M}$ of the NMDA receptor antagonist D-APV was included in the perfusion medium. To isolate NMDA receptor-mediated currents, $10 \mu \mathrm{M}$ of the AMPA/kainate receptor antagonist CNQX was included and magnesium was reduced to $100 \mu \mathrm{M}$. In each of the subsequent experiments presented, slices were perfused with standard ACSF containing $10 \mathrm{~mm}$ glucose before the perfusion medium was changed to one containing $0.2 \mathrm{~mm}$ glucose. Glutamine $(0.5 \mathrm{~mm})$ was included in both conditions. $B$ and $C$, Waveforms were recorded in standardglucose $(l)$ and low-glucose (2) ACSF. Isolated AMPA/kainate $(B)$ and NMDA $(C)$ receptor-mediated pEPSPs werc both reduced by perfusion of low-glucose ACSF after more than $1 \mathrm{hr}$. Asterisk in $C$ indicates the presumed presynaptic fiber volley that did not appear to be affected by low glucose. $D$ and $E$, Presynaptic fiber volleys $(D)$ and antidromic population spikes $(E)$ were isolated in low-calcium ACSF. Neither was reduced after as long as $4 \mathrm{hr}$ of perfusion of medium containing $0.2 \mathrm{~mm}$ glucose. Time scale is the same for all waveforms. Each waveform is an average of 15 consecutive responses.

of increased ASP release prior to depletion of vesicular GLU stores. With further glucose reduction, there was a concentration-dependent reduction in both AMPA/kainate and NMDA receptor-mediated pEPSPs by low-glucose (Fig. 7). Residual NMDA receptor-mediated pEPSPs, however, were significantly larger than residual AMPA/kainate receptor-mediated $\mathrm{pFPSPs}$ ( $p<0.0005$, two-tailed $t$ test corrected for multiple comparisons). Specifically, the amplitude of AMPA/kainate receptormediated pEPSPs declined to $7 \pm 2 \%$ of baseline values whereas the amplitude of NMDA receptor-mediated pEPSPs declined to $34 \pm 3 \%$ at $0.2 \mathrm{~mm}$ glucose (see also Fig. 10). The initial slopes of AMPA/kainate and NMDA receptor-mediated responses also were reduced in $0.2 \mathrm{~mm}$ glucose to $3 \pm 1 \%$ and 36 $\pm 8 \%$ of baseline values, respectively. With glucose omitted

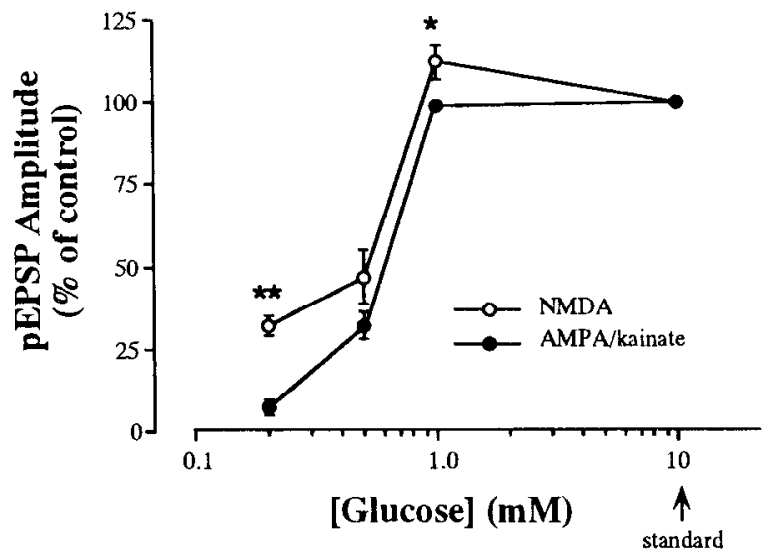

Figure 7. Relative effects of low glucose concentration on isolated AMPA/kainate and NMDA receptor-mediated pEPSPs. AMPA/kainate (solid circles) and NMDA (open circles) receptor-mediated responses were isolated in minislices of area CAl perfused with ACSF containing $10 \mathrm{~mm}$ glucose and $0.5 \mathrm{~mm}$ glutamine. Perfusion medium was then changed to one containing $1.0,0.5$, or $0.2 \mathrm{~mm}$ glucose. AMPA/kainate ( $n=5,5,4$, respectively) and NMDA $(n=5,4,6$, respectively) receptormediated responses were reduced at concentrations below $1.0 \mathrm{~mm}$ glucose. Data are expressed as mean \pm SEM. Asterisks indicate statistically significant differences between groups $\left({ }^{*}, p<0.05 ;{ }^{* *}, p<0.0005\right.$; twotailed $t$ tests corrected for multiple comparisons).

from the ACSF, the amplitude of NMDA receptor-mediated pEPSPs remained at $27 \pm 2 \%$ of their initial amplitude $(n=3)$. These results are consistent with the hypothesis that ASP release mediates a significant proportion of the NMDA receptor-mediated response evoked by Schaffer collateral-commissural stimulation.

An alternative explanation might be that low glucose concentrations are a sufficient metabolic stress to reduce AIP content, decrease membrane potential, and interfere with high-affinity GLU transport. This might cause GLU to accumulate in the synaptic cleft and preferentially desensitize AMPA/kainate receptors, thus causing the preferential reduction in AMPA/ kainate receptor-mediated responses. However, there was no measurable increase in basal release of GLU or ASP by HPLC. In addition, we examined directly several extrasynaptic effects of low glucose. In the experiments described above, presynaptic fiber volleys appeared to be unaffected (Fig. $6 C$ ) by perfusion of low-glucose ACSF over the time course of the experiments. We further verified that reducing glucose concentration did not have nonspecific presynaptic effects by isolating fiber volleys in low-calcium ACSF (0.5 mm), which prevented pEPSPs. Fiber volleys were elicited in area CA1 by electrical stimulation of the Schaffer collateral-commissural afferents in low-calcium ACSF. Reducing glucose from $10 \mathrm{~mm}$ to $0.2 \mathrm{~mm}$ did not reduce the amplitude of presynaptic fiber volleys, even as recorded after $4 \mathrm{hr}$ in low glucose (Fig. 6D). We also assessed the effects of reduced glucose on antidromic population spikes to control for nonspecific postsynaptic effects. Antidromic spikes were elicited in area CA 1 by electrical stimulation of stratum oriens in lowcalcium ACSF. Reduction to $0.2 \mathrm{~mm}$ glucose did not reduce antidromic spike amplitudes, even as recorded after $4 \mathrm{hr}$ in low glucose (Fig. $6 E$ ), but did reduce the polysynaptic components of the same antidromic evoked responses (see late phase of waveforms in Fig. $6 E$ ).

We also obtained intracellular recordings from pyramidal cells in minislices of area CAl in standard- and low-glucose ACSF 
Table 1. Summary of effects of reduced glucose on CA1 pyramidal cells

\begin{tabular}{lrrc} 
& \multicolumn{3}{c}{ Glucose concentration in ACSF } \\
\cline { 2 - 4 } & $10 \mathrm{mM}$ & $1.0 \mathrm{mM}$ & $0.2 \mathrm{mM}$ \\
\hline EPSP amplitude $(\mathrm{mV})$ & $8.3 \pm 1.1$ & $96 \pm 3 \%$ & $42 \pm 10 \%$ \\
Membrane potential $(\mathrm{mV})$ & $69 \pm 5.8$ & $100 \pm 1 \%$ & $103 \pm 3 \%$ \\
Input resistance $(\mathrm{M} \Omega)$ & $63 \pm 3.3$ & $99 \pm 2 \%$ & $91 \pm 9 \%$
\end{tabular}

EPSPs were evoked by stimulation of the Schaffer collateral-commissural afferents in CA1 minislices. Data from $10 \mathrm{~mm}$ condition are expressed as mean $\pm \mathrm{SEM}$ for all 11 experiments; data from $1.0 \mathrm{~mm}(n=8)$ and $0.2 \mathrm{~mm}(n=3)$ conditions are expressed as mean percentage of control \pm SEM.

(see Table 1). After $30 \mathrm{~min}$, intracellularly recorded EPSP amplitudes were slightly reduced in $1.0 \mathrm{~mm}$ and were greatly reduced in $0.2 \mathrm{~mm}$ glucose. Membrane potential and input resistance showed no consistent changes in either condition.

In other experiments, we directly measured ATP content in CAl minislices using a luciferin/luciferase bioluminescence assay as described in Materials and Methods. CAl minislices were incubated for $1 \mathrm{hr}$ in ACSF containing either $10 \mathrm{~mm}, 1.0 \mathrm{~mm}$, or $0.2 \mathrm{~mm}$ glucose. No alternate metabolic source was included in the ACSF. ATP content was calculated relative to known standards and corrected for protein content of the tissue preparations. In three separate experiments, ATP content was not reduced in either 1.0 or $0.2 \mathrm{~mm}$ glucose relative to $10 \mathrm{~mm}$ glucose control (Fig. 8).

From these results, we reject the hypothesis that there is sufficient GLU accumulation in the synaptic cleft to preferentially desensitize AMPA/kainate receptors because low glucose did not measurably increase basal EAA release or reduce fiber volleys, antidromic spikes, membrane potential, input resistance, or cellular ATP content. Therefore, the persistence of the NMDA

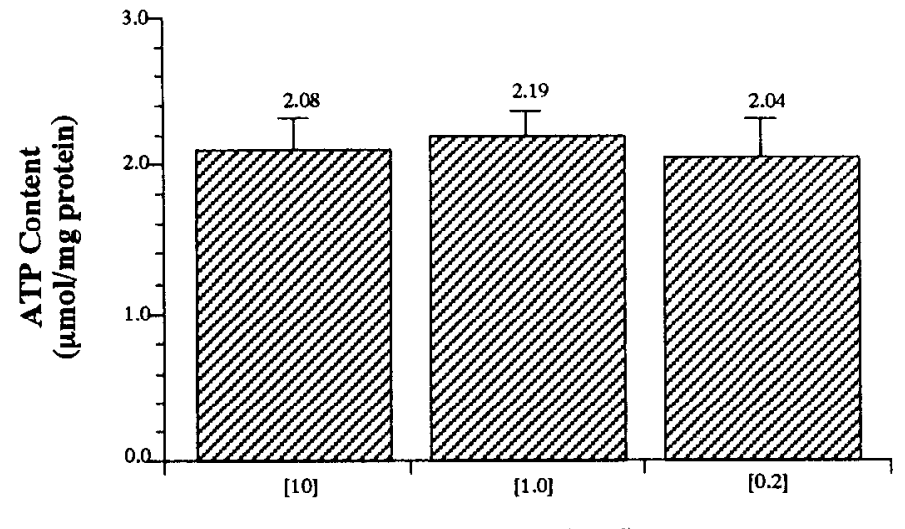

[Glucose] (mM)

Figure 8. Effects of low glucose on cellular ATP content in CA1 minislices. Minislices of area CA1 were preincubated for $1 \mathrm{hr}$ in standard ACSF containing $10 \mathrm{~mm}$ glucose and then scparated into ACSF containing $10,1.0$, or $0.2 \mathrm{~mm}$ glucose. After $1 \mathrm{hr}$ of incubation, slices were collected into a reagent containing an ATP-releasing ionophore, vortexed, and immediately frozen in a dry-ice/ethanol bath. On the day of the assay, sample preparations were rapidly thawed and centrifuged $\left(42,000 \times \mathrm{g}, 5 \mathrm{~min}, 4^{\circ} \mathrm{C}\right) ; 100 \mu \mathrm{l}$ of sample and $100 \mu \mathrm{l}$ of luciferin/ luciferase assay buffer were added to $10 \mathrm{ml}$ of $0.01 \mathrm{M}$ phosphate buffer ( $\mathrm{pH}$ 7.8). Bioluminescence was immediately determined by liquid scintillation spectroscopy. ATP content was determined relative to known standards and corrected for protein content of the samples. Data are expressed as mean \pm SEM for three experiments each run in triplicate.
A

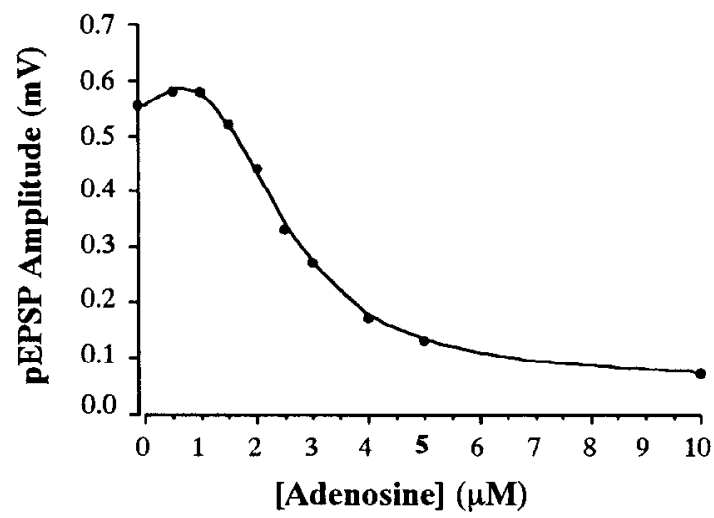

B

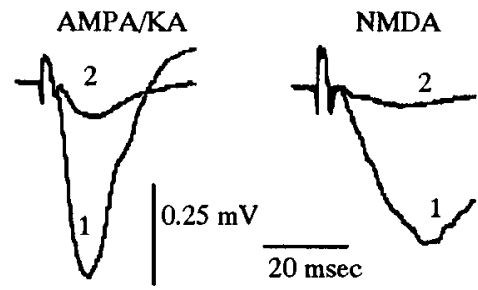

C

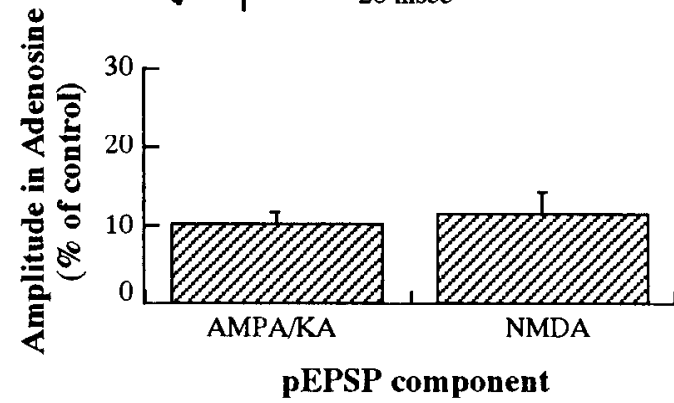

Figure 9. Effects of adenosine on isolated AMPA/kainate and NMDA receptor-mediated pEPSPs in CA 1 minislices. $A$, The concentrationresponse curve was established for adenosine effects on CA1 pEPSPs to derive a concentration that approximates the reduction seen in 0.2 mM glucose. Adenosine reduced pEPSP amplitudes in a concentrationdependent manner showing an apparent $\mathrm{IC}_{50}$ of approximately $3.0 \mu \mathrm{M}$. $B$, Waveforms are shown from a representative experiment in the absence ( 1 ) and the presence (2) of $5.0 \mu \mathrm{M}$ adenosine, which reduced AMPA/kainate and NMDA receptor-mediated pEPSPs to $20 \%$ and $13 \%$, respectively. $C$, On average, adenosine reduced AMPA/kainate $(n=5)$ and NMDA $(n=6)$ receptor-mediated responses equally. Data are expressed as mean \pm SEM.

receptor-mediated currents seems to result from the persistence of ASP release in low-glucose ACSF. Still, these results might also be obtained if GLU alone were acting as a neurotransmitter in these synapses by virtue of its relatively higher affinity for NMDA receptors than for AMPA/kainate receptors. That is, if NMDA receptors are more nearly saturated than AMPA/kainate receptors during synaptic transmission, then it follows that the NMDA receptors should be less susceptible to a decrease in GLU release. This model predicts that NMDA receptormediated responses should also persist when GLU release is reduced by other manipulations, even if ASP release is also reduced. Therefore, control experiments were performed using adenosine to depress synaptic transmission. Adenosine depresses excitatory neurotransmission in area CA1 of the hippocampus (Yoon and Rothman, 1991) via $A_{1}$ receptor regulation of potassium and calcium conductances (Fredholm and Dunwiddie, 1988; Lupica et al., 1992). Adenosine reduces pre- but not 
postsynaptic calcium influx (Schubert et al., 1986) and equally reduces the calcium-dependent release of ASP and GLU from minislices of area CAl (Burke and Nadler, 1988). We obtained a concentration-response curve for the depressant effects of adenosine on pEPSPs in one slice to determine an appropriate concentration to use for subsequent experiments. Adenosine caused a concentration-dependent reduction in pEPSP amplitudes with an apparent $\mathrm{IC}_{50}$ of $3.0 \mu \mathrm{M}$ (Fig. 9A). Subsequent experiments were performed using $5 \mu \mathrm{M}$ adenosine to approximate the synaptic depression in $0.2 \mathrm{~mm}$ glucose. Unlike low glucose, however, adenosine equally reduced the amplitudes of AMPA/kainate $(n=4)$ and NMDA $(n=4)$ receptor-mediated responses (Fig. 9) to $11 \pm 2 \%$ and $12 \pm 3 \%$ of baseline, respectively; initial slopes were also equally reduced to $16 \pm 2 \%$ and $11 \pm 2 \%$ of baseline, respectively.

Similar results were obtained using TTX to depress synaptic transmission. TTX $(0.4 \mu \mathrm{M})$ did not preferentially reduce AMPA kainate receptor-mediated responses. Rather, TTX reduced AMPA/kainate $(n=5)$ and NMDA $(n=6)$ receptor-mediated pEPSPs to $32 \pm 8 \%$ and $22 \pm 5 \%$ of their baseline amplitudes, respectively. It should be noted that, although TTX effectively reduces synaptic transmission, it is not an ideal control. Unlike low glucose or adenosine, TTX drastically reduced presynaptic fiber volleys as well as pEPSPs, suggesting that it probably reduces the number of terminals contributing to the synaptic response rather than reducing the amount of transmitter released per terminal.

Alternatively, if NMDA receptors are more nearly saturated, then an increase in GLU release should preferentially enhance AMPA/kainate receptor-mediated responses. We tested this hypothesis by adding 4-AP to the perfusion medium. 4-AP enhances synaptic transmission by blocking potassium channels, thereby increasing calcium influx and transmitter release (Jankowska et al., 1977; Buckle and Haas, 1982; Jones and Heinemann, 1987; Storm, 1988; Muller and Lynch, 1989; Perreault and Avoli, 1989; Muller and Misgeld, 1991). Although the effects are not entirely presynaptic, low concentrations of 4-AP (5-50 $\mu \mathrm{M})$ that have little or no effect on membrane potential effectively block potassium channels involved in spike repolarization (Perreault and Avoli, 1989). A concentration-response curve for effects of 4-AP was derived using the amplitude of the evoked population spike to determine an appropriate concentration for subsequent experiments. 4-AP produced a concentration-dependent enhancement of population spikes with an apparent $\mathrm{EC}_{50}$ of $\sim 5 \mu \mathrm{M}$ (Fig. 10A). Concentrations greater than $50 \mu \mathrm{M}$ caused an initial increase in pEPSP amplitudes followed by an irreversible depression. Subsequent experiments were performed using $10 \mu \mathrm{M}$ 4-AP. Stimulus intensity was set to elicit $p E P S P s$ that were less than half-threshold for spike elicitation to minimize pEPSP contamination by population spikes. Addition of $10 \mu \mathrm{M}$ 4-AP to the perfusion medium did not preferentially enhance AMPA/kainate receptor-mediated responses. Rather, 4-AP enhanced the amplitudes of AMPA/ kainate $(n-8)$ and NMDA $(n=8)$ receptor-mediated pEPSPs to $206 \pm 24 \%$ and $248 \pm 22 \%$ of baseline, respectively (Fig. $10 B$ ). In this case, initial slope is a more appropriate measure of synaptic efficacy because population spikes, which can confound the measurement of pEPSP amplitudes, were more easily elicited in the presence of 4-AP. Population spikes were often elicited even when stimulus intensity was reduced to match pEPSP amplitudes with baseline. Initial slopes of AMPA/kainate and NMDA receptor-mediated pEPSPs were enhanced to
A

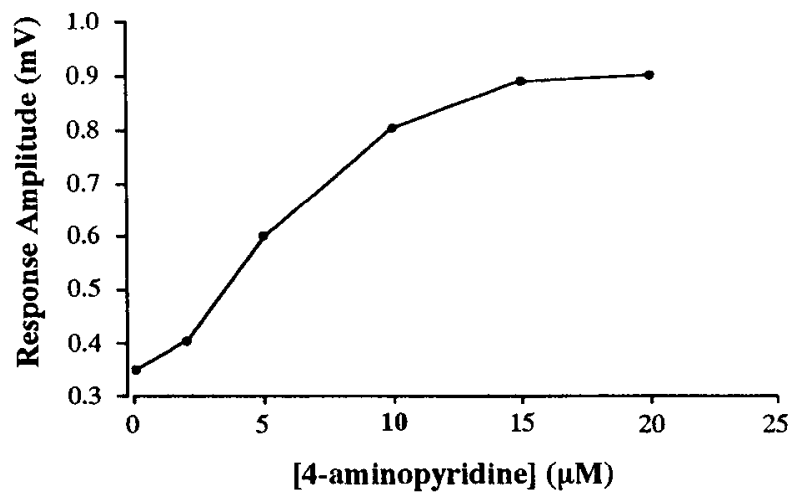

B

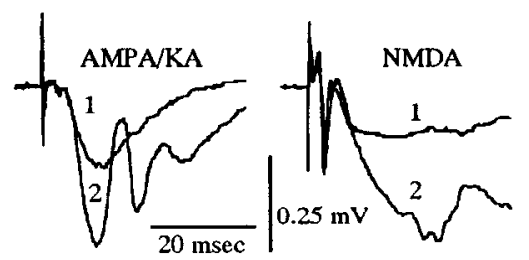

C

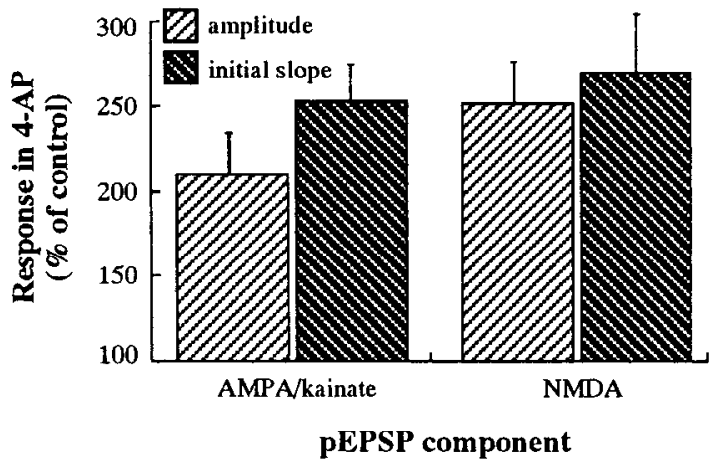

Figure 10. Effects of 4-AP on isolated AMPA/kainate and NMDA receptor-mediated pEPSPs. $A$, The concentration-response curve for 4-AP effects was derived from the amplitude of synchronous population spikes and showed an apparent $\mathrm{EC}_{50}$ of $\sim 5 \mu \mathrm{M}$. The population spike measure was used because of the difficulty obtaining pure pEPSPs in 4-AP without contamination by population spikes. $B$, pEPSPs were recorded in the absence ( 1 ) and the presence (2) of $10 \mu \mathrm{M} 4-\mathrm{AP}$, which enhanced both AMPA/kainate $(n=8)$ and NMDA $(n=8)$ receptormediated responses in CA 1 minislices. $C$, Both pEPSP amplitudes (light bars) and pEPSP initial slopes (dark bars) were measured as an index of synaptic efficacy. Bar graph represents mean \pm SEM.

$252 \pm 16 \%$ and $270 \pm 40 \%$ of baseline, respectively, in 4-AP. Presynaptic fiber volleys isolated in low calcium were not increased in amplitude, but were slightly longer in duration. This is consistent with 4-AP prolongation of action potentials by preferentially blocking the potassium channels involved in spike repolarization. Further, this result suggests that the number of fibers contributing to the synaptic response was not increased, nor were the fibers depolarized by this concentration of 4-AP. The enhanced population spiking suggests that 4-AP affects the length constant of cells both pre- and postsynaptically, making 4-AP a less than ideal control. However, this result should be considered together with results of adenosine and TTX, both of which reduce EAA release generally and produce an equal reduction in AMPA/kainate and NMDA receptor-mediated responses. It is unlikely then that a general reduction of synaptic transmission can explain the differential effects of low glucose on these responses. 


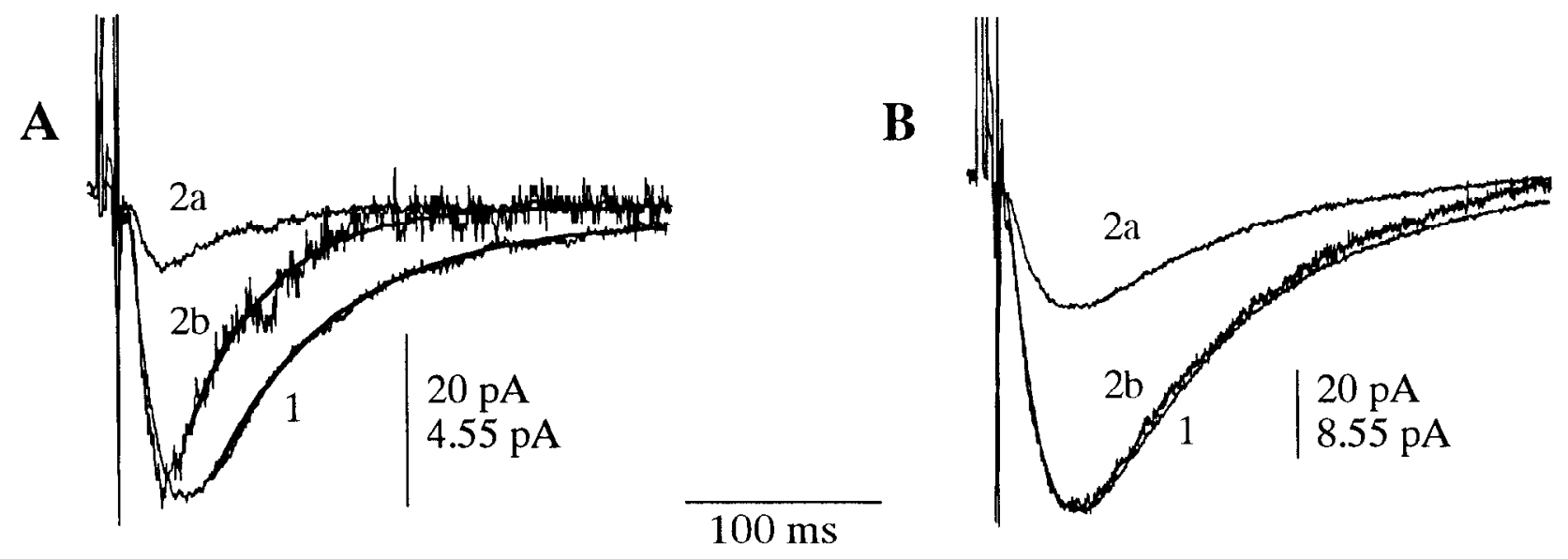

Figure 11. Effects of low glucose $(A)$ and adenosine $(B)$ on NMDA receptor-mediated EPSCs measured by whole-cell recording. $A$, EPSCs were recorded in $10 \mathrm{mM}(1)$ and $0.2 \mathrm{mM}(2 a)$ glucose $(n=6)$. EPSCs from a representative experiment are shown, which were reduced to $20 \%$ of control amplitude in $0.2 \mathrm{~mm}$ glucose. Responses recorded in low glucose were normalized to control amplitude and the time course of decay was fit satisfactorily by a single exponential ( $2 b$ ). Decay-time constants for this experiment were $77 \mathrm{msec}$ in standard- and $43 \mathrm{msec}$ in low-glucose ACSF. Exponential fits are overlaid in waveforms 1 and $2 b . B$, As above, EPSCs were recorded in the absence $(1)$ and the presence $(2 a)$ of $3.5 \mu \mathrm{M}$ adenosine $(n=2)$. EPSCs from a representative experiment are shown that were reduced to $30 \%$ of control amplitude in adenosine. Responses recorded in the presence of adenosine were normalized to control amplitude and the time course of decay was fit by a first-order exponential ( $2 b$ ). Decay-time constants for this experiment were $83 \mathrm{msec}$ in the absence and $88 \mathrm{msec}$ in the presence of adenosine. Exponential fits are overlaid in waveforms $l$ and $2 b$. Waveforms are averages of 15 consecutive responses.

Finally, it has been reported that the decay-time constant of NMDA receptor-mediated currents is determined by agonist affinity (Lester and Jahr, 1992). Specifically, the decay-time constant is approximately $40 \%$ faster for ASP-evoked than GLUevoked NMDA receptor-mediated currents in cultured hippocampal neurons. Assuming this property is retained in adult hippocampal neurons, then NMDA receptor-mediated currents should decay faster in low glucose if in fact ASP mcdiatcs a larger proportion of the synaptic response in this condition. We obtained whole-cell recordings of pure NMDA receptor-mediated EPSCs from pyramidal cells in CAl minislices. Wholecell recordings were obtained after $0.5-3 \mathrm{hr}$ incubation in lowglucose $(0.2 \mathrm{~mm})$ ACSF. Membrane voltage was clamped to $-50 \mathrm{mV}$. After a stable baseline response was established, the perfusion source was changed to standard ACSF containing 10 mM glucose. In low glucose, EPSC amplitudes averaged to 25 $\pm 5 \%$ of control (Fig. 10). The time course of decay was fit satisfactorily with a first-order exponential and in every case ( $n$ $=6$ ) was significantly faster in low glucose, as was readily apparent from the normalized EPSC waveforms (Fig. 11 $A$ ). Decaytime constants of the first-order exponential fits averaged $73 \pm$ $4 \mathrm{msec}$ in standard- and $54 \pm 5 \mathrm{msec}$ in low-glucose ACSF ( $p$ $<0.001$ using one-tailed paired $t$ test). Thus, NMDA receptormediated currents decaycd an average of $26 \%$ faster in low glucose. Similar experiments were performed with adenosine (Fig. $11 B$ ), which reduces ASP and GLU release equally and does not differentially reduce the pEPSP components in extracellular experiments already described. Adenosine $(3.5 \mu \mathrm{M})$ reduced EPSC amplitudes to $\sim 35 \%$ of control, but did not shorten the decay-time constants of NMDA receptor-mediated EPSCs $(n=2)$. Decay-time constants for these whole-cell currents averaged $73 \mathrm{msec}$ during baseline and $78 \mathrm{msec}$ after washing in adenosine.

\section{Discussion}

Together, these data confirm that ASP is involved in synaptic transmission in area CA1 of the hippocampus. ASP is released in a calcium-dependent manner upon depolarization of terminals in area CA 1 and is a potent agonist of hippocampal NMDA but not AMPA/kainate receptors. Low-glucose perfusion preferentially reduced the potassium-evoked release of GLU, but not ASP. Likewise, low glucose preferentially reduced AMPA/ kainate receptor-mediated pEPSPs, for which GLU is a potent agonist, more than NMDA receptor-mediated pEPSPs, for which ASP is also a potent agonist. In contrast, the inhibitory neuromodulator adenosine, which equally reduces ASP and GLU release, equally reduced AMPA/kainate and NMDA receptormediated pEPSPs. If low glucose caused a depletion of ATP or buildup of extracellular GLU due to decreased uptake, one would expect to see a corresponding reduction in membrane potential and input resistance of the postsynaptic cells. However, we saw no evidence of any such nonspecific effects on fiber volleys, antidromic spikes, membrane potential, input resistance, or cellular ATP content. In addition, NMDA receptor-mediated EPSCs showed significantly faster decay-time constants in low glucose, as expected if the lower-affinity agonist, ASP, is preferentially released. Therefore, we conclude that ASP release normally underlies a component of excitatory synaptic responses elicited in area CA1, specifically through its action at NMDA receptors.

Our results also indicate that potassium-evoked EAA release is a reliable index of neurotransmitter release at the synapse for several reasons. First, the potassium-evoked EAA release we observed was entirely calcium dependent. Although high potassium can also evoke calcium-independent EAA release, which is probably not representative of the transmitter pool, this only occurs at higher concentrations or with longer exposure (see Bernath, 1992). Second, a similar increase in the proportion of ASP release has also been reported by electrical stimulation (Szerb and O'Regan, 1987). Third, if $\Lambda$ SP release were an artifact of reversed uptake, due to high extracellular potassium concentration and simultaneous GLU binding, a decrease in GLU release should always be correlated with a decrease in ASP release since both are taken up by the same high-affinity trans- 
porter (Baclar and Johnson, 1972; Flott and Seifert, 1991). This argument is commonly used to explain why ASP rclcasc is calcium dependent (i.e., calcium-dependent GLU release is required to evoke ASP release). Clearly, this was not the case since the decreased GLU release we observed in $0.2 \mathrm{~mm}$ glucose was associated with a compensatory increase in ASP release. Lastly, our release data generated two predictions that were substantiated by experimental observations. That is, the data correctly predicted that the NMDA receptor-mediated component of the synaptic response should persist and that NMDA receptor-mediated EPSCs should decay faster in low glucose.

These results confirm that ASP/GLU homeostasis is altered by conditions that affect neuronal metabolism, such as hypoglycemia as previously described (Sandberg et al., 1986; Szerb and O'Regan, 1987; Szerb, 1988; Nadler et al., 1990). Further, the present findings provide substantial physiological evidence that ASP and GLU are both released synchronously and are both involved in excitatory synaptic transmission at Schaffer collateral-commissural-CA1 synapses of the hippocampus. One interesting question is whether or not ASP is released in vesicles. A vesicular uptake carrier has been identified for GLU but not for ASP (Naito and Ueda, 1985). This has led to the suggestion that either ASP is not a neurotransmitter at all or it is released by some alternate mechanism. Our data suggest that, in this system at least, ASP release is vesicular. This is because ASPmediated NMDA responses measured by whole-cell recording were evoked with the same latency as GLU-mediated NMDA responses. This would not be expected if they were released by different mechanisms. Therefore, a vesicular-uptake carrier for ASP probably does exist in hippocampus; otherwise, it should be considered that both ASP and GLU might be released in a nonvesicular manner (Tauc and Poulain, 1991).

Based on these results alone, however, it is not possible to determine whether ASP and GLU are concomitantly released from different terminals or co-released from the same terminals. The first hypothesis holds that ASP and GLU are released from independent synapses on common target cells. According to this hypothesis, there may be a subset of aspartatergic terminals and a subset of glutamatergic terminals. Unless cells can differentially select their transmitter at the level of the terminal, it follows that these terminals would have to arise from distinct cell populations. For example, perhaps aspartatergic cells project to the contralateral hippocampus via the commissural projection and glutamatergic cells project ipsilaterally via the Schaffer collaterals. Such a relationship has been suggested on the basis of release experiments performed after lesioning the hippocampal commissure (Nadler et al., 1986). By itself, ASP is not likely to produce a postsynaptic response because the NMDA receptors for which it is specific hardly contribute to fast synaptic transmission (Collingridge et al., 1983; Herron et al., 1986). However, aspartatergic terminals could substantially enhance fast glutamatergic transmission when the two inputs converge, causing a larger NMDA response. This mechanism is attractive for its potential relevance to the pathogenesis of epileptic seizures that are associated with enhanced ASP release and no change in GLU release (Flavin et al., 1991). In addition, such a mechanism could provide a novel anatomical basis for associativity in the induction of long-term potentiation.

The second hypothesis holds that ASP and GLU are co-released from the same terminals. According to this hypothesis, both ASP and GLU are synthesized in conjunction with cellular metabolism (see Fig. 1), they are presumably packaged into synaptic vesicles, and they are co-released from the same Schaf- fer collateral-commissural terminals. This hypothesis seems more likely since ASP and GLU both exist in high cytoplasmic concentrations and are readily interconverted by a single enzymatic transamination. In addition, the co-release model is attractive because it provides a potential target for the regulation of synaptic efficacy, ASP transaminase (ASP-T). That is, ASP and GLU are derived from intermediates of the TCA cycle as well as from glutamine and readily interconverted by ASP-T or a similar enzyme in the nerve terminal (Cooper, 1988). The regulation of ASP/GLU homeostasis, and thus of synaptic efficacy, should follow the law of mass action (i.e., depend on the relative concentrations of glucose and glutamine) and depend on the relative affinity of ASP-T for its substrates, which would influence its preferred direction. It is possible that reductions in synaptic efficacy, such as long-term depression, may be associated with increased ASP synthesis and release. On the contrary, enhancements of synaptic transmission, such as long-term potentiation, may be associated with increased GLU synthesis and release. Any such increase in GLU release would preferentially enhance AMPA/kainate receptor activation more than NMDA receptor activation, as is seen with long-term potentiation (Muller et al., 1987).

Either of these models could explain the present results. Decreased glucose should decrease glutamatergic and increase aspartatergic transmission whatever the source, and our electrical field stimulus undoubtedly activated both collateral and commissural fibers. Future experiments will attempt to determine the origin of the releasable pools and assess the roles of ASP, GLU, and ASP-T in the regulation of hippocampal synaptic efficacy.

\section{References}

Baclar V.I, Johnson GAR (1972) The structural specificity of the highaffinity uptake of $\mathrm{L}$-glutamate and $\mathrm{L}$-aspartate by rat brain slices. $\mathrm{J}$ Neurochem 19:2657-2666.

Bekkers JM, Stevens CF (1989) NMDA and non-NMDA receptors are co-localized at individual synapses in cultured rat hippocampus. Nature 341:230-233.

Benveniste H (1989) Brain microdialysis. J Neurochem 52:1667-1679.

Bernath S (1992) Calcium-independent release of amino acid neurotransmitters: fact or artifact? Prog Neurobiol 38:57-91.

Blanton MG, Lo Turco JJ, Kriegstein AR (1989) Whole cell recording from neurons in slices of reptilian and mammalian cerebral cortex. J Neurosci Methods 30:203-210.

Buckle PJ, Haas HL (1982) Enhancement of synaptic transmission by 4-aminopyridine in hippocampal slices of the rat. J Physiol (Lond) 326:109-122.

Burke SP, Nadler JV (1988) Regulation of glutamate and aspartate release from slices of the hippocampal CA 1 area: effects of adenosine and baclofen. J Neurochem 51:1541-1551.

Collingridge GL, Kehl SJ, McLennan H (1983) Excitatory amino acids in synaptic transmission in the Schaffer collateral-commissural pathway of the rat hippocampus. J Physiol (Lond) 334:33-46.

Cooper AJL (1988) L-Glutamate (2-oxoglutarate) aminotransferases. In: Glutamine and glutamate in mammals. (Kvamme E, ed), pp 319. Boca Raton, FL: CRC.

Cotman CW, Nadler JV (1981) Glutamate and aspartate as hippocampal transmitters: biochemical and pharmacological evidence. In: Glutamate: transmitter in the central nervous system (Roberts PJ, Storm-Mathisen J, Johnston GAR, eds), pp 117-154. New York: Wiley.

Cotman CW, Monaghan DT, Ottersen OP, Storm-Mathisen J (1987) Anatomical organization of excitatory amino acid receptors and their pathways. Trends Neurosci 10:273-280.

Dunlop J, Fear A, Griffiths R (1991) Glutamate uptake into synaptic vesicles-inhibition by sulphur amino acids. Neuroreport 2:377-379.

Fagg GE, Foster AC (1983) Amino acid neurotransmitters and their pathways in the mammalian central nervous system. Neuroscience 9:701-719. 
Ferkany JW, Coyle JT (1983) Evoked release of aspartate and glutamate: disparities between prelabeling and direct measurement. Brain Res 278:279-282.

Flavin HJ, Wieraszko A, Seyfried TN (1991) Enhanced aspartate release from hippocampal slices of epileptic (EL) mice. J Neurochem 56:1007-1011.

Fleck MW, Palmer AM, Barrionuevo G (1991) Rclcasc of aspartatc and glutamate from hippocampal slices: implications for the expression of LTP. Soc Neurosci Abstr 17:161.19.

Flott B, Seifert W (1991) Characterization of glutamate uptake systems in astrocyte primary cultures from rat brain. Glia 4:293-304.

Fonnum F (1984) Glutamate: a neurotransmitter in mammalian brain. J Neurochem 41:1-11.

Fonnum F (1988) Excitatory amino acid pathways and the biochemical architecture of the glutamate terminal. In: Frontiers in excitatory amino acid research (Cavalhiero E, Lehmann J, Turski L, eds), pp 85-92. New York: Liss.

Fredholm BB, Dunwiddie TV (1988) How does adenosine inhibit transmitter release? Trends Pharmacol Sci 9:130-134.

Gundersen V, Ottersen OP, Storm-Mathisen J (1991) Aspartate- and glutamate-like immunoreactivities in rat hippocampal slices: depolarization-induced redistribution and effects of precursors. Eur J Neurosci 3:1281-1299.

Hamberger AC, Chiang GH, Nylen ES, ScheffSW, Cotman CW (1979a) Glutamate as a CNS transmitter. I. Evaluation of glucose and glutamine as precursors for the synthesis of preferentially released glutamate. Brain Res 168:513-530.

Hamberger AC, Chiang GH, Sandoval E, Cotman CW (1979b) Glutamate as a CNS transmitter. II. Regulation of synthesis in the releasable pool. Brain Res 168:531-541.

Herron CE, Lester RA, Coan EJ, Collingridge GL (1986) Frequencydependent involvement of NMDA receptors in the hippocampus: a novel synaptic mechanism. Nature 322:265-267.

Hertz L, Schousboe A (1988) Metabolism of glutamate and glutamine in neurons and astrocytes in primary culture. In: Glutamine and glutamate in mammals (Kvamme E, ed), pp 39-55. Boca Raton, FL: CRC.

Hestrin S, Nicoll RA, Perkel DJ, Sah P (1990) Analysis of excitatory synaptic action in pyramidal cells using whole-cell recording from rat hippocampal slices. J Physiol (Lond) 422:203-225.

Jankowska E, Lundberg A, Rudomin P, Sykova E (1977) Effects of 4-aminopyridine on transmission in excitatory and inhibitory synapses in the spinal cord. Brain Res 136:387-392.

Jones KA, Baughman RW (1991) Both NMDA and non-NMDA subtypes of glutamate receptors are concentrated at synapses on cerebral cortical neurons in culture. Neuron 7:593-603.

Jones RSG, Heinemann U (1987) Pre- and postsynaptic $\mathrm{K}^{+}$and $\mathrm{Ca}^{2+}$ fluxes in area CAl of the rat hippocampus in vitro: effects of $\mathrm{Ni}^{2+}$ TEA, and 4-AP. Exp Brain Res 68:205-209.

Lehmann J, Hutchison AJ, McPhereson SE, Mondadori C, Schmutz M, Sinton CM, Tsai C, Murphy DE, Steel DJ, Williams M, Cheney DL, Wood PL (1988) CGS 19755, a selective and competitive $N$-methyl-D-aspartate-type excitatory amino acid receptor antagonist. J Pharmacol Exp Ther 246:65-75.

Lester RAJ, Jahr CE (1992) NMDA channel behavior depends on agonist affinity. J Neurosci 12:635-643.

Lester RAJ, Clements JD, Westbrook GI, Jahr CF, (1990) Channel kinetics determine the time course of NMDA receptor-mediated synaptic currents. Nature 346:565-567.

Lupica CR, Proctor WR, Dunwiddie TV (1992) Presynaptic inhibition of excitatory synaptic transmission by adenosine in rat hippocampus: analysis of unitary EPSP variance measured by whole-cell recording. J Neurosci 12:3753-3764.

Martin D, Bustos AG, Bowe MA, Bray SD, Nadler JV (1991) Autoreceptor regulation of glutamate and aspartate release from slices of the hippocampal CAl area. J Neurochem 56:1647-1655.

Mayer ML, Westbrook GL (1984) Voltage-dependent block by $\mathrm{Mg}^{2+}$ of NMDA responses in spinal cord neurons. Nature 309:261-263.

Mayer ML, Westbrook GL (1987) The physiology of excitatory amino acids in the vertebrate central nervous system. Prog Neurobiol 28: 197-276.

Monaghan DT, Bridges RJ, Cotman CW (1987) The excitatory amino acid receptors: their classes, pharmacology, and distinct properties in the function of the central nervous system. Annu Rev Pharmacol Toxicol 29:365-402.
Muller D, Lynch G (1989) Rate-limiting step for transmission at excitatory synapses in hippocampus. Synapse 3:67-73.

Muller D, Joly M, Lynch G (1987) Contributions of QUIS and NMDA receptors to the induction and expression of LTP. Science 242:156158.

Muller W, Misgeld U (1991) Picrotoxin- and 4-aminopyridine-induced activity in hilar neurons in the guinea pig hippocampal slice. J Neurophysiol 65:141-147.

Murphy DE, Snowhill EW, Williams M (1987) Characterization of quisqualate recognition sites in rat brain tissue using $\mathrm{DL}-\left[{ }^{3} \mathrm{H}\right] \alpha$-amino3-hydroxy-5-methylisoxazole-4-propionic acid (AMPA) and a filtration assay. Neurochem Res 12:775-782.

Murphy DE, Hutchison AJ, Hurt SD, Williams M, Sills MA (1988) Characterization of the binding of $\left[{ }^{3} \mathrm{H}\right]-\mathrm{CGS} 19755$ : a novel $N$-methyl-D-aspartate antagonist with nanomolar affinity in rat brain. $\mathrm{Br} \mathrm{J}$ Pharmacol 95:932-938.

Nadler JV, Vaca KW, White WF, Lynch GS, Cotman CW (1976) Aspartate and glutamate as possible transmitters of excitatory hippocampal afferents. Nature 260:538-540.

Nadler JV, Martin D, Bustos GA, Burke SP, Bowe MA (1990) Regulation of glutamate and aspartate release from the Schaffer collaterals and other projections of CA3 hippocampal pyramidal cells. In: Progress in brain research, Vol 83 (Storm-Mathisen J, Zimmer J, Ottersen OP, eds), pp 115-130. New York: Elsevier.

Naito S, Ueda T (1985) Characterization of glutamate uptake into synaptic vesicles. J Neurochem 44:99-109.

Nicholls DG (1989) Release of glutamate and aspartate from isolated nerve terminals. J Neurochem 52:331-341.

Nowak L, Bregestovski P, Ascher P, Herbert A, Prochiantz A (1984) Magnesium gates glutamate-activated channels in mouse central neurons. Nature 307:462-465.

Olverman HJ, Jones AW, Mewett KN, Watkins JC (1988) Structure/ activity relations of $\mathrm{N}$-methyl-D-aspartate receptor ligands as studied by their inhibition of $\mathrm{D}-\left[{ }^{3} \mathrm{H}\right] 2$-amino-5-phosphonopentanoic acid binding in rat brain membranes. Neuroscience 26:17-31.

Orrego F (1979) Criteria for the identification of central neurotransmitters, and their application to studies with some nerve tissue preparations in vitro. Neuroscience 4:1037-1057.

Palmer AM, Reiter CT, Botscheller M (1992) Comparison of the release of exogenous and endogenous EAAs. Ann NY Acad Sci 648: 361-364.

Patneau DK, Mayer ML (1990) Structure activity relationships for amino acid transmitter candidates acting at NMDA and quisqualate receptors. J Neurosci 10:2385-2399.

Perreault P, Avoli M (1989) Effects of low concentrations of 4 -aminopyridine on CA 1 pyramidal cells of the hippocampus. J Neurophysiol 61:953-970.

Reynolds I (1990) Modulation of NMDA receptor responsiveness by neurotransinitters, drugs and chemical modification. Life Sci 47:17851792.

Sandberg M, Butcher SP, Hagberg H (1986) Extracellular overflow of neuroactive amino acids during severe insulin-induced hypoglycemia: in vivo dialysis of the rat hippocampus. J Neurochem 47:178-184.

Schubert P, Heinemann U, Kolb R (1986) Differential effects of adenosine on pre- and postsynaptic calcium fluxes. Brain Res 376:382386.

Shank RP, Aprison MH (1988) Glutamate as a neurotransmitter. In: Glutamine and glutamate in mammals (Kvamme E, ed), pp 3-19. Boca Raton, FL: CRC.

Smith PK, Krohn RI, Hermanson GT, Mallia AK, Gartner FH, Provenzano MD, Fujimoto EK, Goeke NM, Olson BJ, Klenk DC (1985) Measurement of protein using bicinchoninic acid. Anal Biochem 150: $76-85$

Spencer HJ, Tominez G, Halpern B (1981) Mass spectrographic analysis of stimulated release of endogenous amino acids from rat hip pocampal slices. Brain Res 212:194-197.

Storm JF (1988) Temporal integration by a slowly inactivating $\mathrm{K}^{+}$ current in hippocampal neurons. Nature 336:379-382.

Surtees L, Collins GGS (1985) Receptor types mediating the excitatory actions of exogenous L-aspartate and L-glutamate in rat olfactory cortex. Brain Res 334:287-295.

Szerb JC (1988) Changes in the relative amounts of aspartate and glutamate released and retained in hippocampal slices during stimulation. J Neurochem 50:219-224.

Szerb JC, O'Regan PA (1985) Effect of glutamine on glutamate release 
from hippocampal slices induced by high $\mathrm{K}^{+}$or by electrical stimulation: interaction with different $\mathrm{Ca}^{2+}$ concentrations. $\mathrm{J}$ Neurochem 44:1724-1731.

Szerb JC, O'Regan PA (1987) Reversible shifts in the $\mathrm{Ca}^{2+}$-dependent release of aspartate and glutamate from hippocampal slices with changing glucose concentrations. Synapse 1:265-272.

Tauc L, Poulain B (1991) Vesigate hypothesis of neurotransmitter release explains the formation of quanta by a non-vesicular mechanism. Physiol Res 40:279-291.

Tildon JT, Zielke HR (1988) Glutamine: an energy source for mammalian tissues. In: Glutamine and glutamate in mammals (Fonnum F, ed), pp 167-182. Boca Raton, FL: CRC.

Van den Pol AN (1991) Glutamate and aspartate immunoreactivity in hypothalamic presynaptic axons. J Neurosci 11:2087-2101.

Verdoorn TA, Dingledine R (1988) EAA receptors expressed in Xenopus oocytes: agonist pharmacology. Mol Pharmacol 34:298-307.
Villanueva S, Orrego F (1988) Endogenous ligands for the quisqualate receptor: presence in rat brain cortex synaptic vesicles. Brain Res 440: 363-365.

Villanueva S, Fiedler J, Orrego F (1990) A study in rat brain cortex synaptic vesicles of endogenous ligands for $N$-methyl-D-aspartate receptors. Neuroscience 37:23-30.

Wierasko A (1983) Glutamic and aspartic acid as putative neurotransmitters: release and uptake studies on hippocampal slices. In: Neurobiology of the hippocampus (Seifert W, ed), pp 175-196. New York: Academic.

Yoon KW, Rothman SM (1991) Adenosine inhibits excitatory but not inhibitory synaptic transmission in the hippocampus. J Neurosci 11:1375-1380. 